\title{
Knowledge of community around Dental Hospital of Faculty of Dentistry Universitas Padjadjaran (RSGM FKG Unpad) regarding street dentistry
}

\author{
Lu’lu' Nikhlatur Rif'ah*, Gilang Yubiliana*, Dede Sutardjo* \\ *Department of Community Dentistry Faculty Of Dentistry Universitas Padjadjaran
}

\begin{abstract}
The knowledge of society regarding "dental quack/street dentistry" can determine the individual's behaviors in responding their existence Knowledge influenced by education, employment, age, interest, experience, culture, and source of information. The purpose of this study was to determine the knowledge of community around Dental Hospital of Faculty of Dentistry Universitas Padjadjaran regarding "dental quack/street dentistry". This study was a descriptive study with survey techniques. Samples were taken by purposive sampling method with the sample size of 99 people. The result of this study showed that majority knowledge of the community was less than $40.40 \%$. The conclusion of this study was the knowledge of community around Dental Hospital of Faculty of Dentistry Universitas Padjadjaran regarding "dental quack/street dentistry" was low.
\end{abstract}

Keywords: The knowledge, community around dental hospital, dental quack, street dentistry

\section{INTRODUCTION}

A healthy oral health is a condition where the teeth and surrounding tissues are free from tooth decay, diseases on tooth tissue and tissues surrounding the oral cavity ${ }^{1}$ Dental and oral health can be affected so we must maintain good oral health to keep the teeth and mouth from various diseases.

Oral and dental health is very important. If someone has a problem in oral health, they will find ways to cure it. Health rehabilitation behavior is the kind behavior to conduct or seek treatment, such as self-medicate or seek treatment for modern health facilities (hospital, orderly, dental clinic, etc.), as well as traditional health facilities (shaman, sinshe, etc. .). ${ }^{2}$ According National SocioEconomic Survey conducted in 2001, 57.7\% of Indonesians are self-medicating, $31.7 \%$ are using traditional medicine, and $9.8 \%$ choose traditional treatment.

One of the treatment that most people in
Indonesia look for if they have their dental problems are "dental quack". Dental quack in Indonesia included in one of the cultural phenomenon. This shows that until now the culture still provides a place for dental quack.

Based on research by Sukamto conducted in Kelurahan Cigending Kecamatan Ujung Berung Kota Bandung about dental quack phenomenon shows that from six informants 50\% said they go for dental services from dental quack and $50 \%$ never use dental services from dental quack. Based on the informant, most of people still receives dental treatment from dental quack in making of denture and others dental treatment. ${ }^{3}$

Dental quack phenomenon dental quack can also be seen in all parts of Indonesia including Bandung city. One of the urban village located in Bandung City is Lebakgede in subdistrict of Coblong which was the location for this research.

The location of the study was determined based on pre-research surveys with criteria of 
dental quack in Lebakgede urban-village, around Dental Hospital of Faculty of Dentistry Universitas Padjadjaran (RSGM FKG Unpad) which never researched before.

Dental quack/street dentistry in Lebakgede urban village offers denture making to braces. The absence of specialist educational institutions and skills of dental quack creates a dilemma on the feasibility of opening public health-related practices with the educational background and skills of dental quack.

The existence of dental quack/street dentistry is very difficult to remove because people do not question it. Legally and scientifically, the dentist's profession has a stronger position compared to dental quack, but dental quack was still more accepted by the community. ${ }^{3}$

Ignorance of knowledge about dental quack became one of the factors of public behavior in responding to the existence of dental quack. Knowledge itself are influenced by age, source of information, economic status, education level, and occupation.

Based on the above background, the authors were interested to conducted research on the knowledge of the community about dental quack located in Lebakgede urban village of Coblong sub-district, in the city of Bandung, which were located around Dental Hospital of Faculty of Dentistry Universitas Padjadjaran. The purpose of this study was to determine the knowledge of community around Dental Hospital of Faculty of Dentistry Universitas Padjadjaran regarding “dental quack/street dentistry".

\section{METHODS}

This research used descriptive survey technique. Descriptive survey is a study conducted to describe or describe a phenomenon that occurs in society. ${ }^{4}$ Population taken for this research is the community in Lebakgede urban village, subdistrict of Coblong, in the city of Bandung which was located around Dental Hospital of Faculty of Dentistry Universitas Padjadjaran. The sampling technique used in this study was the purposive sampling so that from the total population of
2,352 people obtained the number of samples of 99 respondents. This study used a questionnaire contained a series of questions about something related to the similar. The questionnaire was intended as the list of questions to obtain data in the form of answers from the respondents. ${ }^{5}$

\section{RESULTS}

The result of the research was obtained by giving questionnaires to the community in Lebakgede urban village, sub-district of Coblong, in the city of Bandung which was located around Dental Hospital of Faculty of Dentistry Universitas Padjadjaran, comprised of the Hamlets of 02, 03,14 , and 15 , with population criterion that has been determined prior to the study, with the total number of respondents as many as 99 people with the aim to determined the toothbrushing knowledge level. Sampling method using the purposive sampling method. Data obtained from the questionnaire.

Characteristics of respondents consisted of gender, age, and socio-economic conditions included education and employment.

Table 1. Characteristics of respondents by gender

\begin{tabular}{|c|c|c|}
\hline Gender & f & $\%$ \\
\hline Male & 48 & 48,48 \\
\hline Female & 51 & 51,51 \\
\hline Total & 99 & 100 \\
\hline
\end{tabular}

From Table 1 can be seen that the female respondents was found more than male, with the ratio of 51 people $(51.51 \%)$ to 48 people $(48.48 \%)$

Table 2. Characteristics of respondents by age

\begin{tabular}{|c|c|c|}
\hline Age & $\mathbf{f}$ & $\%$ \\
\hline $15-29$ & 43 & 43.43 \\
\hline $30-44$ & 33 & 33.33 \\
\hline $45-59$ & 15 & 15.15 \\
\hline $60-75$ & 8 & 8.08 \\
\hline Total & 99 & 100 \\
\hline
\end{tabular}

From Table 2 can be seen that most of the respondents were between 15-29 years old which was as many as 43 people $(43.43 \%)$, while a small number of respondents were aged between 60-75 years with as much as 8 people $(8.08 \%)$. 
Table 3. Characteristics of respondents by level of education

\begin{tabular}{|l|c|c|}
\hline \multicolumn{1}{|c|}{ Education } & f & \% \\
\hline $\begin{array}{l}\text { Not going to } \\
\text { school }\end{array}$ & 1 & 1.01 \\
\hline $\begin{array}{l}\text { Unfinished ele- } \\
\text { mentary school }\end{array}$ & 5 & 5.05 \\
\hline $\begin{array}{l}\text { Graduated ele- } \\
\text { mentary school }\end{array}$ & 9 & 9.09 \\
\hline $\begin{array}{l}\text { Unfinished junior } \\
\text { school }\end{array}$ & 2 & 2.02 \\
\hline $\begin{array}{l}\text { Graduated junior } \\
\text { school }\end{array}$ & 9.09 \\
\hline $\begin{array}{l}\text { Unfinished high } \\
\text { school }\end{array}$ & 1 & 5.05 \\
\hline $\begin{array}{l}\text { High school } \\
\text { student }\end{array}$ & 35 & 1.01 \\
\hline $\begin{array}{l}\text { Graduated high } \\
\text { school }\end{array}$ & 2 & 35.35 \\
\hline Unfinished college & 14 & 14.14 \\
\hline College student & 16 & 16.16 \\
\hline Graduated college & 0 & 0.00 \\
\hline Others & 99 & 100 \\
\hline Total & & \\
\hline
\end{tabular}

From Table 3 can be seen that most of respondents education level were high school graduated with as much as 35 people (35.35\%), 16 college graduated (16.16\%), 14 college students $(14.14 \%)$, and the smallest education level was high school student and uneducated with as much as 1 person (1.01\%).

Table 4. Characteristics of respondents based on job

\begin{tabular}{ccc}
\hline Occupation & $\mathbf{f}$ & $\%$ \\
Student & 18 & 18.18 \\
Government officer & 2 & 2.02 \\
Private employee & 23 & 26.26 \\
Entrepreneur & 18 & 18.18 \\
Indonesian National & 0 & 0.00 \\
Armed Forces & 7 & 7.07 \\
Worker & 0 & 0.00 \\
Farmer & 6 & 6.06 \\
Merchant & 3 & 3.03 \\
Pensionary & 21 & 21.21 \\
Housewife & 1 & 1.01 \\
Unemployed & 0 & 0.00 \\
Others & 99 & 100 \\
\hline Total & &
\end{tabular}

From Table 4 can be seen that most of the respondents occupations were private employee which was found in as much as
23 people (26.26\%), housewife in 21 people $(21,21 \%)$, entrepreneur and student found in as much as 18 people (18.18\%), workers found in 7 people $(7.07 \%)$, merchants found in 6 people $(6.06 \%)$, pensionary found in 3 people $(3.03 \%)$, government officer found in 2 people $(2.02 \%)$ and unemployed was found in 1 person $(1.01 \%)$. No respondents with the occupation of Indonesian National Armed Forces and farmers (0\%).

Table 5 showed that the majority of respondents (84 respondents, 84.84\%) knew the difference between dentist and dental quack. Table 5 also showed that as much as 68 people $(68.68 \%)$ did not know the regulation of dental practice.

Table 6 showed that most of the respondents had low knowledge regarding dental quack/street dentistry (40 people, $40.40 \%$ ), the moderate knowledge frequency was found in 37 people $(37.37 \%)$ and only a few respondent were having good knowledge (22 people, 22.22\%). Community knowledge was influenced by socioeconomic, cultural, and educational conditions. Therefore, there was a connection between these two variables.

Based on Table 7 found that from 48 male respondents, 10 people $(10.10 \%)$ had a good level of knowledge, 17 people (17.17\%) had moderate level of knowledge, and 21 people $(21.21 \%)$ have a low level of knowledge.

Based on Table 8 found that from 43 respondents aged between 15-29 years old, as much as $7.07 \%$ had a good level of knowledge, $19.19 \%$ had a moderate level of knowledge, and $17.17 \%$ had a low level of knowledge. From 33 respondents aged between 30-44 years old, as much as $12.12 \%$ had a good level of knowledge, $11.11 \%$ had moderate knowledge level, and $10.10 \%$ had low level of knowledge. From 15 respondents aged between 45-59 years old, as much as 5 people have a moderate level of knowledge while 10 others have a low knowledge level. From 8 respondents aged 60 years old and over, as much as 3 people (3.03\%) had a good level of knowledge, 2 people $(2.02 \%)$ had a moderate level of knowledge and 3 others (3.03\%) had a low level of knowledge.

Table 9 showed that uneducated respondents were having medium knowledge regarding dental quack (1.01\%). While the respondents who were having elementary, junior high, and senior high school education have the low level of knowledge, 6 people (6.06\%), 7 people $(7.07 \%)$, and 19 people (19.19\%) respectively. This was different from respondents who have college education, with majority were having good level of knowledge regarding dental quack (11 respondents). 
Table 5. Results of knowledge assessment based on questionnaire

\begin{tabular}{|c|c|c|c|c|c|c|}
\hline \multirow{2}{*}{ No } & \multirow{2}{*}{ Questions } & \multicolumn{2}{|c|}{ True } & \multicolumn{2}{|c|}{ False } & \multirow{2}{*}{ Total } \\
\hline & & f & $\%$ & f & $\%$ & \\
\hline 1 & Definition of dental quack & 43 & 43.43 & 56 & 56.56 & 100 \\
\hline 2 & Differences between dental quack and dentist & 84 & 84.84 & 15 & 15.15 & 100 \\
\hline 3 & Differences between dental quack and dental technician & 69 & 69.69 & 30 & 30.30 & 100 \\
\hline 4 & Dental quack equipments & 73 & 73.73 & 26 & 26.26 & 100 \\
\hline 5 & Different ways of promotion between dental quack and dentist & 43 & 43.43 & 56 & 56.56 & 100 \\
\hline 6 & Law regulation regarding dental quack & 31 & 31.31 & 68 & 68.68 & 100 \\
\hline 7 & $\begin{array}{l}\text { Government permission should obtained for dental quack/ } \\
\text { street dentistry practice }\end{array}$ & 39 & 39.39 & 60 & 60.60 & 100 \\
\hline 8 & Dental quack/street dentistry practice scope & 59 & 59.59 & 40 & 40.40 & 100 \\
\hline 9 & Dental quack/street dentistry skill & 43 & 43.43 & 56 & 56.56 & 100 \\
\hline 10 & $\begin{array}{l}\text { Skill and knowledge of dental quack regarding oral and dental } \\
\text { health care }\end{array}$ & 81 & 81.81 & 18 & 18.18 & 100 \\
\hline
\end{tabular}

Table 6. Community around Dental Hospital of Faculty of Dentistry Universitas Padjadjaran regarding dental quack/street dentistry

\begin{tabular}{ccc}
\hline Knowledge & f & $\%$ \\
Good & 22 & 22.22 \\
Average & 37 & 37.37 \\
Below average & 40 & 40.40 \\
\hline Total & 99 & 100 \\
\hline
\end{tabular}

Table 7 Relationship between gender and level of knowledge

\begin{tabular}{|c|c|c|c|c|c|c|c|c|}
\hline \multirow{3}{*}{ Gender } & \multicolumn{6}{|c|}{ Knowledge level } & \multirow{2}{*}{\multicolumn{2}{|c|}{ Total }} \\
\hline & \multicolumn{2}{|c|}{ Good } & \multicolumn{2}{|c|}{ Average } & \multirow{2}{*}{$\begin{array}{r}\text { Less } \\
\mathrm{f}\end{array}$} & & & \\
\hline & $f$ & $\%$ & $f$ & $\%$ & & $\%$ & $f$ & $\%$ \\
\hline Male & 10 & 10.10 & 17 & 17.17 & 21 & 21.21 & 48 & 48.48 \\
\hline Female & 12 & 12.12 & 20 & 20.20 & 19 & 19.19 & 51 & 51.51 \\
\hline Total & 22 & 22.22 & 37 & 37.37 & 40 & 40.40 & 99 & 100 \\
\hline
\end{tabular}

Table 8 Relationship between age and level of knowledge

\begin{tabular}{|c|c|c|c|c|c|c|c|c|}
\hline \multirow{3}{*}{ Age } & \multicolumn{6}{|c|}{ Knowledge level } & \multirow{2}{*}{\multicolumn{2}{|c|}{ Total }} \\
\hline & \multicolumn{2}{|c|}{ Good } & \multicolumn{2}{|c|}{ Average } & \multicolumn{2}{|c|}{ Less } & & \\
\hline & $f$ & $\%$ & $f$ & $\%$ & f & $\%$ & $f$ & $\%$ \\
\hline $15-29$ age & 7 & 7.07 & 19 & 19.19 & 17 & 17.17 & 43 & 43.43 \\
\hline $30-44$ age & 12 & 12.12 & 11 & 11.11 & 10 & 10.10 & 33 & 33.33 \\
\hline 45-59 age & 0 & 0 & 5 & 5.05 & 10 & 10.10 & 15 & 15.15 \\
\hline 60 age and above & 3 & 3.03 & 2 & 2.02 & 3 & 3.03 & 8 & 8.08 \\
\hline Total & 22 & 22.22 & 37 & 37.37 & 40 & 40.40 & 99 & 100 \\
\hline
\end{tabular}


Knowledge of community around Dental Hospital regarding street dentistry (Lu'Lu' Nikhlatur Rif'ah et al.)

Table 10. Relationship between occupation and level of knowledge

\begin{tabular}{|c|c|c|c|c|c|c|c|c|}
\hline \multirow{3}{*}{ Occupation } & \multicolumn{6}{|c|}{ Knowledge level } & \multirow{2}{*}{\multicolumn{2}{|c|}{ Total }} \\
\hline & \multicolumn{2}{|c|}{ Good } & \multicolumn{2}{|c|}{ Average } & \multicolumn{2}{|c|}{ Less } & & \\
\hline & $f$ & $\%$ & $f$ & $\%$ & $f$ & $\%$ & $f$ & $\%$ \\
\hline Student & 5 & 5.05 & 6 & 6.06 & 7 & 7.07 & 18 & 18.18 \\
\hline Government officer & 0 & 0 & 0 & 0 & 2 & 2.02 & 2 & 2.02 \\
\hline Private employee & 7 & 7.07 & 8 & 8.08 & 8 & 8.08 & 23 & 23.23 \\
\hline Entrepreneur & 4 & 4.04 & 8 & 8.08 & 6 & 6.06 & 18 & 28.28 \\
\hline Worker & 0 & 0 & 4 & 4.04 & 3 & 3.03 & 7 & 7.07 \\
\hline Merchant & 2 & 2.02 & 1 & 1.01 & 3 & 3.03 & 6 & 6.06 \\
\hline Pensionary & 2 & 2.02 & 0 & 0 & 1 & 1.01 & 3 & 3.03 \\
\hline Housewive & 2 & 2.02 & 10 & 10.10 & 9 & 9.09 & 21 & 21.21 \\
\hline Unemployed & 0 & 0 & 0 & 0 & 1 & 1.01 & 1 & 1.01 \\
\hline Total & 22 & 22.22 & 37 & 37.37 & 40 & 40.40 & 99 & 100 \\
\hline
\end{tabular}

Table 11. Frequency of dental quack treatment

\begin{tabular}{ccc}
\hline Visit to dental quack & $\mathbf{f}$ & $\%$ \\
More than 1 time & 16 & 16.16 \\
1 time & 11 & 11.11 \\
Never & 72 & 72.72 \\
\hline Total & 99 & 100 \\
\hline
\end{tabular}

Table 12. Needs for dental quack treatment

\begin{tabular}{ccc}
\hline Needs for visit to dental quack & f & $\%$ \\
Denture & 11 & 40.74 \\
Filling & 9 & 33.33 \\
Extraction & 6 & 22.22 \\
Scaling & 1 & 3.70 \\
\hline Total & 27 & 100 \\
\hline
\end{tabular}

Table 13. Motivation for having dental quack treatment

\begin{tabular}{ccc}
\hline Motivation for having dental quack treatment & $\mathrm{f}$ & $\%$ \\
Self-motivated & 21 & 77.78 \\
Family & 1 & 3.70 \\
Neighbour/Friends & 5 & 18.52 \\
\hline Total & 27 & 100 \\
\hline
\end{tabular}

Table 14. Reasons for having dental quack treatment

\begin{tabular}{ccc}
\hline Reasons for having dental quack treatment & f & $\%$ \\
Familiarity & 6 & 22.22 \\
Near from house & 6 & 22.22 \\
Accessible & 3 & 11.11 \\
Low cost & 12 & 44.44 \\
\hline Total & 27 & 100 \\
\hline
\end{tabular}


Table 10 showed the relationship of occupation to the knowledge of the community regarding the dental quack. The table showed that respondents who work as private employees, majority have medium knowledge and less that was equal to 8 people $(8,08 \%)$. While majority housewives have knowledge that amounted to 10 people.

From Table 11 found that most of the samples were (72 people, $72.72 \%$ ) never came to the dental quack, the second most frequent was respondents who had come more than one visit as many as 16 people $(16.16 \%)$ and at least one respondent who had once treated 11 people (11.11\%).

Based on Table 12 known that of the 27 people who ever went to the Dental quack, as many as 9 people $(33.33 \%)$ came to the dental quack for filling, making dentures as much as 11 people $(40.74 \%)$, tooth extraction $6(22.22 \%)$, and the least were the respondents who came to the dental quack for dental scaling was only 1 person (5\%).

From Table 13 can be seen that almost all respondents who came to the dental quack due to self-motivation were as much as 21 people $(77,78 \%)$, very few of the respondents do the visit due to the invitation from friends or neighbors as many as 5 people $(18.52 \%)$, and very few others only 1 person $(3.70 \%)$ because of the invitation of the family.

Based on Table 14 can be seen that from 27 people who have come to the dental quack, as much as 12 people (44.44\%) have reason to go to dental quack due to the low cost, the second and third because they know the dental quack and near from house in as much as 6 people (22.22\%), and the least of the respondents who came due to easy accessibility were as much as 3 people (11.11\%).

\section{DISCUSSION}

The results showed that the majority knowledge of community around Dental Hospital of Faculty of Dentistry Universitas Padjadjaran regarding dental quack/street dentistry was low. The respondents are sampled in accordance with the criteria that have been determined by researchers, namely the community in Lebakgede urban village that was the Hamlets of 02,03, 14, and 15 located around Dental Hospital of Faculty of Dentistry Universitas Padjadjaran. The results of this study can be seen in Table 6 which showed that most respondents were having low level of knowledge (40 respondents, $40.40 \%$ ).

Based on Table 5 showed that 84 respondents know the difference of dental quack with dentist that was equal to $84,84 \%$. In addition, 69 respondents also know the difference of dental quack with dental technician that was equal to $69.69 \%$. This happened because the research location is close to a dental hospital and the dental quack so that people can compare how they differ. This is in line with the theory that knowledge is the result of "knowing" and this occurs after people make sense to an object. Unlike the case with Meutuah (2009) which examined 40 communities in Medan Amplas and Medan Denai subdistrict, Amplas indicated that $67.5 \%$ of respondents did not know about the difference of dental quack and dentists as this was influenced by economic condition, social status, community culture, and environment different. ${ }^{6}$

Although the respondents knew the difference between the dental quack and the dentist, the average respondent did not know the definition of the dental quack. This can be seen from the results of the study showed that only $43.43 \%$ of respondents who know the understanding of the dental quack.

Table 5 showed that 73 respondents (73.73\%) correctly answer the question about the equipment used by the dental quack. This showed that the community knew that the equipment used by the dental quack was not as complete as owned by the dentist. The majority of respondents knew it because by seeing the dentist's premises located at the dental hospital with the dental quack practice was very different. Dentists' premises have adequate facilities. This is very different from the dental quack practice place that has a very simple practice place. In the Regulation of the Minister of Health of the Republic of Indonesia No. 339/Menkes/Per/V/1989 mentioned that the dental quack in doing his work using ways and tools that most have in common with dentistry tools but do not have education in the field of dentistry.

Table 5 showed that 43 respondents (43.43\%) answered correctly the question of 
how dental quack and dentists in promoting the practice site. dental quack are different from dentists, one of them in terms of promoting the practice. A dentist has an ethic of Dentistry one of which is in terms of promotion, while the dental quack has no special rules governing it.

Table 5 showed that 59 respondents (59.59\%) knew what dental quack may do in practice. This showed that most respondents knew about the authority of the dental quack is making removable dentures. The authority of the dental quack is stated in the Regulation of the Minister of Health of the Republic of Indonesia No. $339 /$ Menkes/Per/V/1989 but this regulation was revoked by the government with the existence of a new regulation stating that the dental work and instruction manual is revoked and declared null and void.

Table 5 showed that only 31 respondents (31.31\%) know the laws governing the opening of dental practices for dental quack. This happened due to the lack of socialization from the government to inform the law, so that few people know about it. People should know the law, because if people know it then they can participate in supporting the government in disciplining dental quack practices. Table 5 also showed that 39 respondents (39.39\%) knew the permit obtained by the dental quack. Based on Regulation of the Minister of Health of the Republic of Indonesia No. 339/Menkes/ $\mathrm{Per} / \mathrm{V} / 1989$ that the dental quack is required to have a license from the local health authority. Permission is not all dental quack have it. Based on the results of research by Ariny (2002), 25\% of all dental quack respondents in Bandung do not have the permit. ${ }^{7}$

Table 5 showed that 43 respondents (43.43\%) knew the origin of skills acquired by a dental quack. This showed that few respondents know it. Based on the results of research Ariny (2002) showed that the majority of respondents acquire skills in the field of dental quack for generations, which was as much as $82.14 \%{ }^{7}$

Based on the result of this research that has been done, the majority of respondents were having the low level of knowledge regarding the dental quack. The result of this research was influenced by education factor because most of the respondents were only high school graduates and the majority of respondents were private employees and housewives. This can be seen in Table 9 which showed that the majority of people who are educated elementary, junior and senior high school have less knowledge about dental quack.

The results of this study were in line with the theory in the book Notoatmodjo (2010) that knowledge is influenced by age, information sources, economic status, education level, and employment. Although the knowledge of the community about the dental quack was low, but the majority of respondents never to the dental quack was equal to $74.36 \%{ }^{8}$

Because the level of public knowledge about dental quack was low, the community needs to be given information about the dental quack to increase the knowledge of the community and also the socialization of the laws that regulate the dental quack, especially the Regulation of the Minister of Health of the Republic of Indonesia No. 1871/Menkes/Per/IX/2011 mentioned that the dental quack who has carried out his work under the Regulation of the Minister of Health of the Republic of Indonesia No. 339/Menkes/Per/V/1989 on dental work still can carry out its dental work until the enforcement of this rule and/or expired the permit, and can not be renewed. Therefore, it is hoped that in the future there will be no more dental quack/street dentistry practices.

\section{CONCLUSION}

Based on the results of data analysis and discussion that has been done before, the conclusion of this study was the knowledge of community around Dental Hospital of Faculty of Dentistry Universitas Padjadjaran regarding "dental quack/street dentistry" was less.

\section{REFERENCES}

1. World Health Organization [homepage on internet]. Geneva: WHO; 2007 [cited 2012 March] Oral Health; [about 2 screens]. Available from: http://www.who.int/ mediacentre/factsheets/fs318/en/index.htm

2. Notoatmodjo S. Prinsip-Prinsip Dasar Ilmu Kesehatan Masyarakat. Jakarta: Rineka Cipta; 2003. p. 9, 15, 122, 127-30, 139.

3. Sukamto PR. Pandangan Masyarakat di 
Kelurahan Cigending Kecamatan Ujung berung Kota Bandung Tentang Tukang Gigi [minor thesis]. Bandung: Unpad; 2007. p. 30.

4. Notoatmodjo S. Prinsip-Prinsip Dasar IImu Kesehatan Masyarakat. Jakarta: Rineka Cipta; 2003. p. 9, 15, 122, 127-30, 139.Notoatmodjo S. Metodologi Penelitian Kesehatan. Jakarta: Rineka Cipta; 2010. p. 35-6.

5. Koentjaraningrat. Metode-metode Penelitian Masyarakat. Jakarta: Gramedia Pustaka Utama; 1997. p. 173.
6. Meutuah S. Hubungan Karakteristik Pengguna Gigi Palsu dengan Pemanfaatan Jasa Tukang Gigi di Kota Medan Tahun 2008 [minor thesis]. Medan: USU; 2008. p. 64-9.

7. Ariny T. Pelayanan Kesehatan Gigi oleh Tukang Gigi di Kota Bandung Dikaji dari Aspek Profil Pemberi Jasa Serta Kepuasan Pengguna Jasa [minor thesis]. Bandung: Unpad; 2002. p. 7.

8. Notoatmodjo S. Ilmu Perilaku Kesehatan. Jakarta: Rineka Cipta; 2010. p. 2729. 